\title{
Vitamin D deficiency in early childhood: prevalent in the sunny South Pacific
}

\author{
Cameron C Grant ${ }^{1,2, *}$, Clare R Wall ${ }^{3}$, Sue Crengle ${ }^{4}$ and Robert Scragg ${ }^{5}$ \\ 'Department of Paediatrics, Faculty of Medicine and Health Sciences, University of Auckland, Private Bag \\ 92019, Auckland, New Zealand: ${ }^{2}$ General Paediatrics, Starship Children's Hospital, Auckland District Health \\ Board, Auckland, New Zealand: ${ }^{3}$ Discipline of Nutrition, University of Auckland, Auckland, New Zealand: \\ ${ }^{4}$ Te Kupenga Hauora Maori, University of Auckland, Auckland, New Zealand: ${ }^{5}$ Department of Epidemiology \\ and Biostatistics, University of Auckland, Auckland, New Zealand
}

Submitted 17 December 2007: Accepted 7 December 2008: First published online 23 February 2009

\begin{abstract}
Objective: To estimate the prevalence of and risk factors for vitamin D deficiency in young urban children in Auckland, New Zealand, where there is no routine vitamin D supplementation.

Design: A random sample of urban children. Vitamin D deficiency was defined as serum 25-hydroxyvitamin $\mathrm{D}<27 \cdot 5 \mathrm{nmol} / 1(<11 \mathrm{ng} / \mathrm{ml})$. Logistic regression analysis was used to calculate odds ratios and, from these, relative risks (RR) and $95 \%$ confidence intervals were estimated.

Setting: Auckland, New Zealand ( $\left.36^{\circ} 52^{\prime} \mathrm{S}\right)$, where the daily vitamin D production by solar irradiation varies between summer and winter at least 10 -fold.

Subjects: Children aged 6 to 23 months enrolled from 1999 to 2002.

Results: Vitamin D deficiency was present in forty-six of 353 (10\%; 95\% CI 7 , $13 \%)$. In a multivariate model there was an increased risk of vitamin D deficiency associated with measurement in winter or spring (RR $=7 \cdot 24,95 \%$ CI $1 \cdot 55,23 \cdot 58)$, Pacific ethnicity $(\mathrm{RR}=7 \cdot 60,95 \% \mathrm{CI} 1 \cdot 80,20 \cdot 11)$, not receiving any infant or follow-on formula ( $\mathrm{RR}=5 \cdot 69,95 \% \mathrm{CI} 2 \cdot 66,10 \cdot 16)$, not currently receiving vitamin supplements $(\mathrm{RR}=5 \cdot 32,95 \% \mathrm{CI} 2 \cdot 04,11 \cdot 85)$ and living in a more crowded household ( $\mathrm{RR}=2 \cdot 36,95 \%$ CI $1 \cdot 04,4 \cdot 88)$.

Conclusions: Vitamin D deficiency is prevalent in early childhood in New Zealand. Prevalence varies with season and ethnicity. Dietary factors are important determinants of vitamin D status in this age group. Vitamin D supplementation should be considered as part of New Zealand's child health policy.
\end{abstract}

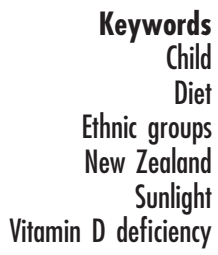

New Zealand is a South Pacific island nation that lies between latitudes $34^{\circ} \mathrm{S}$ and $47^{\circ} \mathrm{S}^{(1)}$. Solar UV radiation is very high in the summer and New Zealand has some of the highest rates of skin cancer in the world ${ }^{(2)}$. Sun protection to prevent skin damage and skin cancer when the UV index is high is an important and necessary health message $^{(3)}$.

However, there are also large seasonal variations in UV radiation in New Zealand, with the daily winter erythemal dose being between $5 \%$ and $10 \%$ of the summer dose ${ }^{(4)}$. The daily vitamin D production by solar UV irradiation varies between summer and winter at least 10-fold in Auckland $\left(36^{\circ} 52^{\prime} \mathrm{S}\right)$ and at least 20-fold in Invercargill $\left(46^{\circ} 24^{\prime} \mathrm{S}\right)^{(5)}$.

In contrast to the USA and the UK, routine vitamin D supplementation during early childhood is not recommended $^{(6,7)}$. Current recommendations in New Zealand are for intakes of $200 \mathrm{IU}$ vitamin $\mathrm{D} / \mathrm{d}$ from birth to age 50 years $^{(8)}$. These same recommendations apply to pregnant and breast-feeding women ${ }^{(9)}$. For premature or low-birth-weight infants $(<32$ weeks' gestation or $<1800 \mathrm{~g}$ ) the recommended intake is $400 \mathrm{IU}$ vitamin $\mathrm{D} / \mathrm{d}$ with oral supplementation if the infant is consuming $<180 \mathrm{ml}$ preterm milk formula or fortified breast milk/kg per $\mathrm{d}^{(10)}$. For children it is recommended that hands, face and arms or arms and legs be exposed to the sun two to three times weekly for 5 to $10 \mathrm{~min}$ (non-pigmented skin) or 10 to $15 \mathrm{~min}$ (pigmented skin). The Cancer Society of New Zealand recommends that this exposure not be between 11.00 and 16.00 hours in the summer months ${ }^{(11)}$.

In Auckland we have observed a significant number of hospitalised children with vitamin D-deficient rickets. Eighteen hospitalised children (median age 12 months) with radiological evidence of rickets and serum 25hydroxyvitamin D $(25(\mathrm{OH}) \mathrm{D})<25 \mathrm{nmol} / 1$ were identified in an audit of one calendar year (1998) of admissions, giving a prevalence of approximately 6 per 10000 children less than 3 years old ${ }^{(12,13)}$. Deficiency of other 
micronutrients (Fe deficiency 14\% and vitamin A deficiency 9\%) are also prevalent in Auckland children aged 6 to 23 months $^{(14)}$. We therefore sought to determine the population prevalence of vitamin D deficiency in the first two years of life and the factors associated with vitamin D deficiency in this age group.

\section{Subjects and methods}

\section{Study design}

An ethnically stratified random sample of children aged 6 to 23 months residing in Auckland was enrolled. In this age group 18\% are Maori (New Zealand's indigenous population), $24 \%$ are Pacific (from Samoa, Tonga and other Pacific Island nations) and $58 \%$ are of European and other ethnic groups ${ }^{(15)}$. There were no exclusion criteria. Enrolment of children with an acute infection was deferred for one month. The Health Funding Authority Ethics Committee approved the study.

Eligible children were identified from random residential address start points with cluster sampling from the twenty consecutive dwellings starting with the dwelling immediately to the right of each start point address. A list of random start points in the form of street addresses was obtained from the New Zealand Department of Statistics. A researcher identified eligible children by visiting the twenty dwellings at each start point.

In a manner identical to that used in the national census, ethnicity was defined by the child's caregiver. This was the parent's ethnicity or the ethnicity they identified with most if the parents were from more than one ethnic group. An ethnically stratified sampling ratio was applied so the enrolled sample would include approximately equal numbers of three groups: Maori, Pacific and European or other children. A sample of 450 children was sufficient to have $95 \%$ confidence limits of $\pm 2 \%$ if the observed prevalence of vitamin D deficiency was $5 \%$ and $\pm 6 \%$ if it was $50 \%{ }^{(16)}$.

Socio-economic status was measured using the New Zealand Index of Social Deprivation ${ }^{(17,18)}$. This measure uses census data that describe household income and ownership, household member employment and education, and household amenities and crowding. Based on these variables households in New Zealand are ranked on a 10-point deprivation scale with 1 being the least deprived and 10 the most deprived households.

\section{Data collection}

Data were collected in the child's home. Written informed consent was obtained, the child's caregiver was interviewed and topical anaesthetic cream applied to the child's antecubital fosse $\left(2.5 \%\right.$ lignocaine, $2.5 \%$ prilocaine, EMLA ${ }^{\mathrm{TM}}$; AstraZeneca Ltd, Auckland, New Zealand).

One hour following application of the anaesthetic cream a paediatric phlebotomist visited and obtained a
$5 \mathrm{ml}$ venous blood sample. This was facilitated by the research nurse using play therapy to assist the child to cope with the venepuncture ${ }^{(19)}$. Blood was collected into trace-element-free Vacutainer tubes, protected from light and oxygen, transported on ice and frozen until analysis.

$25(\mathrm{OH}) \mathrm{D}$ concentration was measured using RIA (DiaSorin, Stillwater, MN, USA). Inter-batch CV was 6.4\% (at $22 \mathrm{nmol} / \mathrm{l}$ ) and intra-batch CV was $6 \cdot 6 \%$ (at $25 \mathrm{nmol} / \mathrm{l}$ ). The assay measured total $25(\mathrm{OH}) \mathrm{D}$ (both vitamin $\mathrm{D}_{2}$ and $\left.\mathrm{D}_{3}\right)$. Vitamin D deficiency was defined as $25(\mathrm{OH}) \mathrm{D}<$ $27 \cdot 5 \mathrm{nmol} / 1(<11 \mathrm{ng} / \mathrm{ml})^{(7,20,21)}$.

A full blood count was measured using an automated Coulter Counter (Beckman Coulter Inc., Fullerton, CA, USA). Serum ferritin concentration was measured by immunoturbidimetry. Serum $\mathrm{Fe}$ and total Fe binding capacity were measured calorimetrically using the FerroZine reagent ${ }^{(22)}$. Fe deficiency was defined as abnormal values for two or more of serum ferritin $(<10 \mu \mathrm{g} / \mathrm{l})$, Fe saturation $(<10 \%)$ and mean cell volume $(<73 \mathrm{fl})^{(14,23,24)}$. C-reactive protein (CRP) concentration was measured by immunoturbidimetry. An elevated CRP was defined as $>4 \mathrm{mg} / \mathrm{l}$.

Weight and length were measured supine. The mean of three serial measurements from each child, wearing light clothing and no shoes, were taken. Height-for-age and weight-for-age $Z$-scores were computed in the Epi-Info ${ }^{\text {TM }}$ 2000 software (Centers for Disease Control and Prevention (CDC), Atlanta, GA, USA) using the 2000 CDC reference data ${ }^{(16)}$.

\section{Statistical analyses}

Double-entered data were analysed using Epi-Info ${ }^{\text {TM }}$ 2000 and the SAS-PC version 9.1 statistical software package (SAS Institute Inc., Cary, NC, USA). Estimations of variable distribution, proportions and odds ratios were adjusted for clustering and weighted for ethnic stratification using SAS-callable SUDAAN version 9·0 1 (Research Triangle Institute, Research Triangle Park, NC, USA).

Univariate associations with vitamin D deficiency were determined by estimating odds ratios and 95\% confidence intervals. Variables examined included those describing the presence of Fe deficiency; season of enrolment; child demographics (age, ethnicity, gestation, birth weight), feeding habits (breast-feeding duration, use of vitamin D-fortified milk formula, weaning foods, use of vitamin and mineral supplements) and UV light exposure; and family and household characteristics. Within each of these areas the potential for covariance was explored. Where covariance was present between pairs of variables only the variable with the strongest association with vitamin D was included in the regression model.

Exposure to UVB radiation was measured indirectly by determining the number of hours the child spent outdoors in the sun during the preceding four weeks. In New Zealand, reported sunlight exposure has been shown to correlate with serum $25(\mathrm{OH}) \mathrm{D}$ concentrations ${ }^{(25)}$. 
A multivariate model was built by successively adding variables in order of the amount of variance in vitamin D deficiency that they explained in univariate analyses. Variables were included in the model if their inclusion increased the explanatory power of the model and if the variable was significantly associated with vitamin D deficiency $(P<0 \cdot 05)$ after adjustment for the effect of other variables previously added to the model.

Multivariate logistic regression analysis was performed using SAS-callable SUDAAN (PROC MULTILOG) to estimate odds ratios and $95 \%$ confidence intervals. As the odds ratios were determined on a cohort in which vitamin D deficiency was prevalent, the relative risk (RR) estimated from the odds ratio was adjusted to more accurately represent the true relative risk $^{(26)}$.

\section{Results}

\section{Study sample enrolment}

Enrolment occurred from June 1999 to September 2002 and is summarised in Fig. 1. Application of the ethnic specific sampling frames resulted in 575 of the 995 identified eligible children being invited to enrol (100\%

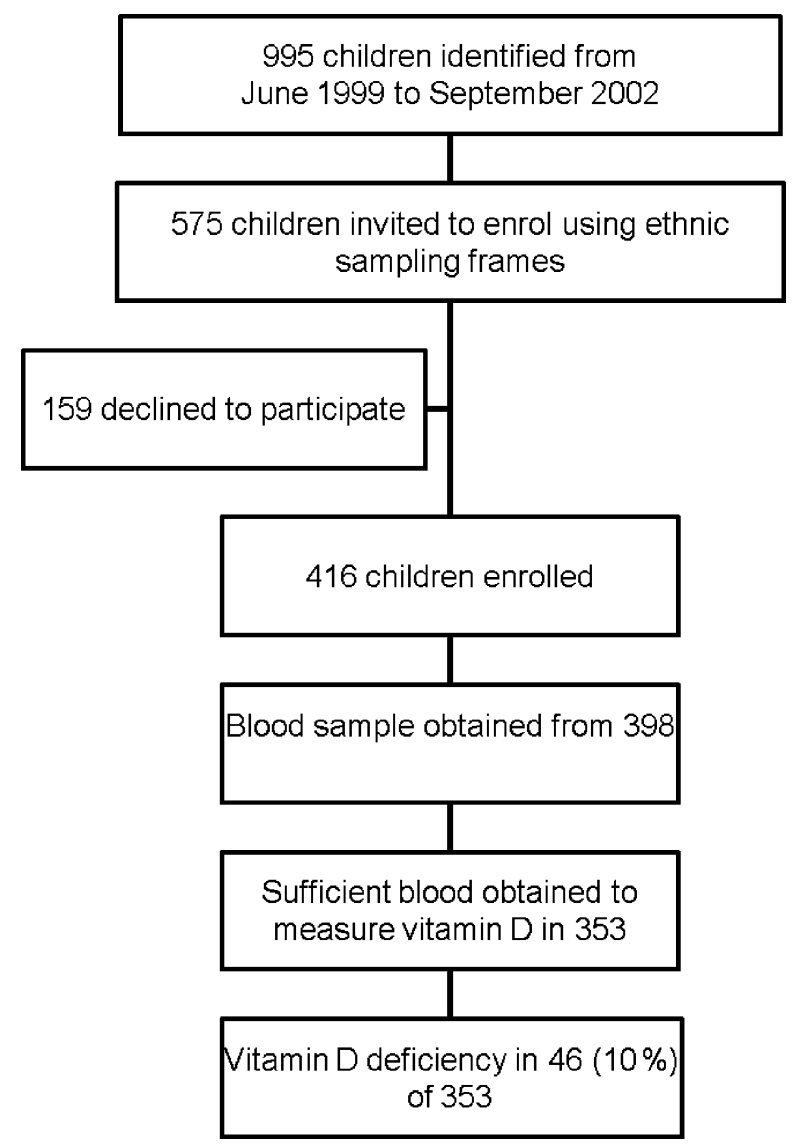

Fig. 1 Summary of enrolment, blood sampling and prevalence of vitamin $D$ deficiency in the studied population: random sample of urban children aged 6 to 23 months, Auckland, New Zealand, 1999-2002 of the identified Maori children, $75 \%$ of the identified Pacific children and $31 \%$ of the identified children of New Zealand European and other ethnic groups).

The most frequently stated reason for non-enrolment was that the caregiver did not want the child to have a blood test. Social deprivation, as measured by the median household deprivation score, did not differ between enrolled ( $n$ 416) $v$. non-enrolled ( $n$ 159). The 416 enrolled children were identified from 345 start points, with between one and five (median one) enrolled from each start point.

Vitamin D status was measured in 353 (85\%) of 416 enrolled children. The median (25th, 75th centile) vitamin D concentration was $55(42,70) \mathrm{nmol} / \mathrm{l}$. Vitamin D deficiency was present in forty-six (10\%; 95\% CI 7, 13\%).

Serum vitamin D concentrations varied with age, ethnicity and season (Table 1). The median vitamin D concentration for children aged 18-23 months was lower than that for children aged 6-11 $(P=0 \cdot 002)$ or $12-17$ months $(P=$ 0.002). In comparison with European children, vitamin D concentrations were lower for Maori $(P=0 \cdot 02)$ and Pacific $(P<0 \cdot 001)$ children. In comparison with those measured in summer, vitamin $\mathrm{D}$ concentrations were lower when measured during winter $(P<0 \cdot 001)$ or spring $(P<0 \cdot 001)$. The median vitamin $\mathrm{D}$ concentration did not differ between children with a normal $v$. elevated $(>4 \mathrm{mg} / \mathrm{l})$ CRP concentration ( $53 v .50 \mathrm{nmol} / \mathrm{l}, P=0.55)$.

\section{Characteristics of the children}

The median age (25th, 75 th centile) was $14 \cdot 7(11 \cdot 0,19 \cdot 6)$ months. Associations of children's ethnicity and feeding habits with risk of vitamin D deficiency are shown in Table 2. There was an increased risk of vitamin D deficiency

Table 1 Vitamin D concentration by age, gender, ethnicity and season: random sample of urban children aged 6 to 23 months, Auckland, New Zealand, 1999-2002

\begin{tabular}{|c|c|c|c|}
\hline \multirow[b]{2}{*}{ Variable } & \multicolumn{2}{|c|}{ Vitamin D concentration $(\mathrm{nmol} / \mathrm{l})$} & \multirow[b]{2}{*}{$P$ value } \\
\hline & Median & 25th, 75th centile & \\
\hline \multicolumn{3}{|l|}{ Age in months $(n 340)^{*}$} & $<0.001$ \\
\hline 6 to $11(n 107)$ & 62 & 42,78 & \\
\hline 12 to $17(n 112)$ & 58 & 44,76 & \\
\hline 18 to $23(n 121)$ & 49 & 39,61 & \\
\hline \multicolumn{4}{|l|}{ Gender (n 353) } \\
\hline Male (n 168) & 57 & 42,75 & $0 \cdot 11$ \\
\hline Female ( $n$ 185) & 52 & 41,67 & \\
\hline \multicolumn{3}{|l|}{ Ethnicity (n 353) } & $<0.001$ \\
\hline Maori ( $n$ 90) & 53 & 36,67 & \\
\hline Pacific (n 120) & 43 & 29,58 & \\
\hline Other $(n 25)$ & 50 & 34,69 & \\
\hline European (n 118) & 59 & 47,76 & \\
\hline \multicolumn{3}{|l|}{ Season $(n$ 353)† } & $<0.001$ \\
\hline Summer (n 47) & 71 & 51,81 & \\
\hline Autumn ( $n 96)$ & 61 & 49,74 & \\
\hline Winter ( $n$ 125) & 47 & 34,63 & \\
\hline Spring $(n 85)$ & 47 & 35,62 & \\
\hline
\end{tabular}

*Seven children were aged 5 months, five children were aged 24 months and one child was aged 27 months when vitamin D status was measured. tSummer (December to February), autumn (March to May), winter (June to August), spring (September to November). 
Table 2 Associations of child's ethnicity and feeding habits, season of enrolment and sunlight exposure with risk of vitamin D deficiency: random sample of urban children aged 6 to 23 months, Auckland, New Zealand, 1999-2002

\begin{tabular}{|c|c|c|c|c|c|c|}
\hline \multirow[b]{3}{*}{ Variable } & \multicolumn{4}{|c|}{ Vitamin D deficiency present } & \multirow[b]{3}{*}{ RRt } & \multirow[b]{3}{*}{$95 \% \mathrm{Cl}+$} \\
\hline & \multicolumn{2}{|c|}{ Yes $(n$ 46) } & \multicolumn{2}{|c|}{ No $(n$ 307) } & & \\
\hline & $n$ & $\% *$ & $n$ & $\% *$ & & \\
\hline \multicolumn{7}{|l|}{ Child's ethnicity and feeding habits } \\
\hline \multicolumn{7}{|l|}{ Ethnic group ( $n$ 353) } \\
\hline Maori & 10 & 11 & 80 & 89 & $4 \cdot 30$ & $1 \cdot 01,13 \cdot 78$ \\
\hline Pacific & 29 & 24 & 91 & 76 & $9 \cdot 14$ & $2 \cdot 78,20 \cdot 35$ \\
\hline Other & 4 & 16 & 21 & 84 & $6 \cdot 14$ & $1 \cdot 14,19 \cdot 63$ \\
\hline European & 3 & 3 & 115 & 97 & $1 \cdot 00$ & \\
\hline \multicolumn{7}{|l|}{ Age stopped breast milk (n 324) } \\
\hline 7 months or older & 11 & 6 & 138 & 94 & $2 \cdot 08$ & $0 \cdot 94,4 \cdot 22$ \\
\hline 0 to 6 months & 30 & 12 & 145 & 88 & $1 \cdot 00$ & \\
\hline \multicolumn{7}{|l|}{ Any infant or follow-on formula (n 350) } \\
\hline No & 23 & 26 & 45 & 74 & $4 \cdot 84$ & $2 \cdot 62,8.03$ \\
\hline Yes & 21 & 5 & 261 & 96 & $1 \cdot 00$ & \\
\hline \multicolumn{7}{|l|}{ Weaning foods first eaten ( $n$ 347) } \\
\hline Only home-made & 15 & 20 & 52 & 80 & $2 \cdot 82$ & $1 \cdot 37,5 \cdot 21$ \\
\hline Commercial and/or home-made & 29 & 7 & 251 & 93 & $1 \cdot 00$ & \\
\hline \multicolumn{7}{|c|}{ Child currently taking vitamin supplements ( $n$ 349) } \\
\hline No & 43 & 10 & 285 & 90 & $3 \cdot 91$ & $2 \cdot 24,6 \cdot 57$ \\
\hline Yes & 1 & 3 & 20 & 97 & $1 \cdot 00$ & \\
\hline \multicolumn{7}{|c|}{ Sunlight exposure and season of enrolment } \\
\hline \multicolumn{7}{|c|}{ Season of enrolmentł } \\
\hline Winter & 27 & 15 & 98 & 85 & $12 \cdot 88$ & $7 \cdot 34,21 \cdot 62$ \\
\hline Spring & 15 & 14 & 70 & 86 & $11 \cdot 84$ & $5 \cdot 90,22 \cdot 36$ \\
\hline Autumn & 3 & 3 & 93 & 97 & $2 \cdot 53$ & $0.41,14.03$ \\
\hline Summer & 1 & 1 & 46 & 99 & $1 \cdot 00$ & \\
\hline \multicolumn{7}{|c|}{ Hours per day outside over past 4 weeks $\S(n 347)$} \\
\hline 0 & 7 & 19 & 23 & 81 & $2 \cdot 17$ & $0 \cdot 84,4 \cdot 67$ \\
\hline 1 or more & 37 & 9 & 280 & 91 & $1 \cdot 00$ & \\
\hline \multicolumn{7}{|c|}{ Clothing and sun protection used when outside } \\
\hline \multicolumn{7}{|c|}{ Long-sleeved top and pants\|l ( $n$ 349) } \\
\hline Yes & 41 & 15 & 164 & 85 & $7 \cdot 57$ & $1 \cdot 33,26 \cdot 87$ \\
\hline No & 3 & 2 & 141 & 98 & $1 \cdot 00$ & \\
\hline \multicolumn{7}{|l|}{ Sunhat ( $n$ 349) } \\
\hline Yes & 23 & 10 & 179 & 90 & $1 \cdot 01$ & $0.53,1 \cdot 85$ \\
\hline No & 21 & 9 & 126 & 91 & $1 \cdot 00$ & \\
\hline \multicolumn{7}{|l|}{ Sunscreen ( $n$ 349) } \\
\hline Yes & 3 & 3 & 92 & 97 & $0 \cdot 18$ & $0 \cdot 03,1 \cdot 13$ \\
\hline No & 41 & 13 & 213 & 87 & 1.00 & \\
\hline
\end{tabular}

$\mathrm{RR}$, relative risk.

${ }^{*}$ Row percentages adjusted for clustering and weighted for the ethnic stratification.

tProportions and relative risks and $95 \%$ confidence intervals weighted for ethnicity and adjusted for clustering.

$\ddagger$ Summer (December to February), autumn (March to May), winter (June to August), spring (September to November).

§Number of hours per day in the last 4 weeks averaged over weekdays and weekend days that the child spent outdoors in the sun.

IIAlternatives include T-shirt and shorts, underpants and singlet, or nothing.

for all non-European ethnic groups with the risk being greatest for children of Pacific ethnicity $(\mathrm{RR}=9 \cdot 14$, 95\% CI $2 \cdot 78,20 \cdot 35)$. Although vitamin D concentration decreased with increasing age the risk of vitamin D deficiency did not vary with age.

Vitamin D status did not vary with birth weight. The mean height-for-age $Z$-score $(0 \cdot 24 v \cdot 0 \cdot 20, P=0 \cdot 81)$ and weight-for-age $Z$-score $(0.62 v .0 .56, P=0.78)$ did not differ between those with low $v$. normal vitamin $\mathrm{D}$ concentrations. Being of premature gestation or low birth weight was not associated with the risk of vitamin D deficiency $(\mathrm{RR}=0 \cdot 47,95 \% \mathrm{CI} 0 \cdot 06,3 \cdot 04)$.

Most (92\%) children were breast-fed. The risk of vitamin D deficiency was not associated with duration of breast-feeding but was increased in children who had not received any milk formula $(\mathrm{RR}=4 \cdot 84,95 \% \mathrm{CI} 2 \cdot 62,8 \cdot 03)$, the only type of milk in New Zealand that is fortified with vitamin D. Milk formula in New Zealand is required to contain between $0 \cdot 25$ and $0.63 \mu \mathrm{g}$ of vitamin $\mathrm{D}_{2}$ or vitamin $\mathrm{D}_{3}$ per $100 \mathrm{~kJ}^{(27)}$.

Children whose first weaning foods were home-made rather than commercial were at increased risk of vitamin $\mathrm{D}$ deficiency $(\mathrm{RR}=2 \cdot 82,95 \% \mathrm{CI} 1 \cdot 37,5 \cdot 21)$ as were those children not currently taking vitamin or mineral supplements ( $\mathrm{RR}=3 \cdot 91,95 \% \mathrm{CI} 2 \cdot 24,6 \cdot 57)$. Children who ate no eggs, meat or fish were not at increased risk of vitamin $\mathrm{D}$ deficiency $(\mathrm{RR}=0 \cdot 68,95 \% \mathrm{CI} 0 \cdot 30,1 \cdot 51)$.

Fourteen per cent of the children were Fe-deficient. The risk of vitamin D deficiency was increased in children with Fe deficiency $(\mathrm{RR}=2 \cdot 50,95 \% \mathrm{CI} 1 \cdot 17,4 \cdot 71)$. 


\section{Season of enrolment and sunlight exposure}

Table 2 also shows associations of season of enrolment and sunlight exposure with risk of vitamin D deficiency. Children enrolled during either winter $(\mathrm{RR}=12 \cdot 88,95 \% \mathrm{CI}$ $7 \cdot 34,21 \cdot 62)$ or spring $(\mathrm{RR}=11 \cdot 84,95 \% \mathrm{CI} 5 \cdot 90,22 \cdot 36)$ were at increased risk of vitamin D deficiency. The median (25th, 75th centiles) number of hours spent outdoors per day over the preceding month was $1 \cdot 5(0 \cdot 9,2 \cdot 3)$. There was no association between spending less than one hour per day outside and the risk of vitamin D deficiency. Nor did the risk of vitamin D deficiency vary with the time of day when the child was usually outside (data not shown). The lack of association between time spent outside and risk of vitamin $\mathrm{D}$ deficiency persisted after adjustment for either season or ethnicity (data not shown). In comparison with children who wore less clothing, children who usually wore a longsleeved top and pants when outside were at increased risk of vitamin D deficiency ( $R R=7 \cdot 57,95 \%$ CI $1 \cdot 33,26 \cdot 87)$.

\section{Parents and siblings}

The median (25th, 75th centile) maternal age was 31 (26, $34)$ years. Family and household characteristics and associated risk of vitamin D deficiency are shown in Table 3. The risk of vitamin D deficiency did not vary with maternal age or education (data not shown). There was an increased risk of vitamin D deficiency if neither parent was employed $(\mathrm{RR}=2 \cdot 34,95 \%$ CI $1 \cdot 02,4 \cdot 69)$. Sixty per cent of the children had siblings. Having two or more siblings was associated with an increased risk of vitamin D deficiency $(\mathrm{RR}=2 \cdot 29,95 \%$ CI $1 \cdot 23,3 \cdot 98)$.

The total household income from wages and benefits, before tax, in the last 12 months was provided for 316 (90\%) of the households. There was an increased risk of vitamin D deficiency associated with annual household income $<$ \$NZ $15000(\mathrm{RR}=2 \cdot 91,95 \% \mathrm{CI} 1 \cdot 13,6 \cdot 02)$ and with a higher household expenditure to income ratio $(\mathrm{RR}=9 \cdot 75,95 \%$ CI $6 \cdot 01,15 \cdot 45)$. Children living in households where there were six or more residents $(\mathrm{RR}=3 \cdot 64,95 \% \mathrm{CI} 1 \cdot 99,6 \cdot 08)$ or in households that were more crowded $(\mathrm{RR}=4 \cdot 11,95 \% \mathrm{CI} 2 \cdot 30,6 \cdot 68)$ were at increased risk of vitamin $\mathrm{D}$ deficiency.

Household income and family size vary with ethnicity, with a larger proportion of Pacific and Maori children living in lower-income and more crowded households $^{(28,29)}$. After adjustment for ethnicity, the increased risk of vitamin D deficiency associated with higher household expenditure to income ratio $(\mathrm{RR}=7 \cdot 98$, 95\% CI $4 \cdot 59,13 \cdot 55)$, and with households that contained more people $(\mathrm{RR}=2 \cdot 19,95 \% \mathrm{CI} 1 \cdot 09,4 \cdot 09)$ and were more crowded $(\mathrm{RR}=2 \cdot 24,95 \%$ CI $1 \cdot 10,4 \cdot 23)$, persisted.

\section{Multivariate analyses}

In the multivariate model (Table 4) there was an increased risk of vitamin D deficiency associated with being enrolled in either winter or spring $(\mathrm{RR}=7 \cdot 24,95 \%$ CI $1 \cdot 55,23 \cdot 58)$, Pacific ethnicity $(\mathrm{RR}=7 \cdot 60,95 \%$ CI $1 \cdot 80$,

Table 3 Family and household characteristics and associated risk of vitamin D deficiency: random sample of urban children aged 6 to 23 months, Auckland, New Zealand, 1999-2002

\begin{tabular}{|c|c|c|c|c|c|c|c|c|}
\hline \multirow[b]{3}{*}{ Variable } & \multicolumn{4}{|c|}{ Vitamin D deficiency present } & & & & \\
\hline & \multicolumn{2}{|c|}{ Yes (n 46) } & \multicolumn{2}{|c|}{ No (n 307) } & \multicolumn{2}{|c|}{ Univariate risk† } & \multicolumn{2}{|c|}{ Adjusted for ethnic group } \\
\hline & $n$ & $\% *$ & $n$ & $\%$ * & $\mathrm{RR}$ & $95 \% \mathrm{Cl}$ & $\mathrm{RR}$ & $95 \% \mathrm{Cl}$ \\
\hline \multicolumn{9}{|c|}{ Family characteristics } \\
\hline \multicolumn{9}{|c|}{ Neither parent employed ( $n$ 316) } \\
\hline Yes & 10 & 19 & 40 & 81 & $2 \cdot 34$ & \multirow[t]{2}{*}{$1 \cdot 02,4 \cdot 69$} & $1 \cdot 65$ & \multirow[t]{2}{*}{$0 \cdot 66,3 \cdot 70$} \\
\hline No & 29 & 8 & 237 & 92 & $1 \cdot 00$ & & $1 \cdot 00$ & \\
\hline \multicolumn{9}{|c|}{ Number of siblings ( $n$ 350) } \\
\hline 2 or more & 20 & 16 & 85 & 84 & $2 \cdot 29$ & \multirow[t]{2}{*}{$1 \cdot 23,3 \cdot 98$} & $1 \cdot 49$ & \multirow[t]{2}{*}{$0 \cdot 75,2 \cdot 82$} \\
\hline 0 or 1 & 24 & 7 & 221 & 93 & $1 \cdot 00$ & & $1 \cdot 00$ & \\
\hline \multicolumn{9}{|c|}{ Household characteristics } \\
\hline \multicolumn{9}{|c|}{$\begin{array}{l}\text { Household income before tax in past } \\
12 \text { months in } \$ N Z \ddagger(n 316)\end{array}$} \\
\hline $1-15000$ & 9 & 22 & 29 & 78 & $2 \cdot 91$ & $1 \cdot 13,6 \cdot 02$ & $1 \cdot 15$ & $0 \cdot 36,3 \cdot 17$ \\
\hline $15001-40000$ & 15 & 8 & 110 & 92 & $1 \cdot 09$ & \multirow[t]{2}{*}{$0 \cdot 48,2 \cdot 33$} & 0.53 & \multirow[t]{2}{*}{$0 \cdot 25,1 \cdot 13$} \\
\hline 40001 or greater & 15 & 8 & 138 & 92 & $1 \cdot 00$ & & $1 \cdot 00$ & \\
\hline \multicolumn{9}{|c|}{ Household expenditure to income ratio ( $n$ 296) } \\
\hline 0.34 or greater & 35 & 11 & 212 & 89 & $9 \cdot 75$ & \multirow[t]{2}{*}{$6 \cdot 01,15 \cdot 45$} & $7 \cdot 98$ & \multirow[t]{2}{*}{$4 \cdot 59,13 \cdot 55$} \\
\hline$<0.34$ & 1 & 1 & 48 & 99 & $1 \cdot 00$ & & $1 \cdot 00$ & \\
\hline \multicolumn{9}{|c|}{ Number of people living in house ( $n$ 348) } \\
\hline Six or more & 21 & 23 & 68 & 77 & $3 \cdot 64$ & \multirow[t]{2}{*}{$1 \cdot 99,6 \cdot 08$} & $2 \cdot 19$ & \multirow[t]{2}{*}{$1 \cdot 09,4 \cdot 09$} \\
\hline Two to five & 23 & 6 & 236 & 94 & $1 \cdot 00$ & & $1 \cdot 00$ & \\
\hline \multicolumn{9}{|c|}{ Person to room ratio ( $n 348$ ) } \\
\hline $1 \cdot 0$ or greater & 22 & 25 & 62 & 75 & $4 \cdot 11$ & \multirow[t]{2}{*}{$2 \cdot 30,6 \cdot 68$} & $2 \cdot 24$ & \multirow[t]{2}{*}{$1 \cdot 10,4 \cdot 23$} \\
\hline$<1 \cdot 0$ & 22 & 6 & 242 & 94 & $1 \cdot 00$ & & $1 \cdot 00$ & \\
\hline
\end{tabular}

$\mathrm{RR}$, relative risk.

${ }^{*}$ Row percentages adjusted for clustering and weighted for the ethnic stratification.

tProportions and relative risks and $95 \%$ confidence intervals weighted for ethnicity and adjusted for clustering

fFrom all sources in the past 12 months including wages and benefits, before tax or any other deductions. 
Table 4 Multivariate analysis of risk factors for vitamin D deficiency: random sample of urban children aged 6 to 23 months, Auckland, New Zealand, 1999-2002

\begin{tabular}{|c|c|c|c|c|}
\hline \multirow[b]{2}{*}{ Variable } & \multicolumn{2}{|c|}{ Univariate risk* } & \multicolumn{2}{|c|}{ Multivariate risk* ${ }^{*}$} \\
\hline & $\mathrm{RR}$ & $95 \% \mathrm{Cl}$ & RR & $95 \% \mathrm{Cl}$ \\
\hline \multicolumn{5}{|l|}{ Season } \\
\hline Winter and spring & $6 \cdot 23$ & $1 \cdot 55,19 \cdot 39$ & $7 \cdot 24$ & $1 \cdot 55,23 \cdot 58$ \\
\hline Summer and autumn & $1 \cdot 00$ & & $1 \cdot 00$ & \\
\hline \multicolumn{5}{|l|}{ Ethnic group } \\
\hline Maori & $4 \cdot 30$ & $1 \cdot 01,13 \cdot 78$ & $3 \cdot 41$ & $0.66,13.06$ \\
\hline Pacific & $9 \cdot 14$ & $2 \cdot 78,20 \cdot 35$ & $7 \cdot 60$ & $1 \cdot 80,20 \cdot 11$ \\
\hline Other & $6 \cdot 14$ & $1 \cdot 14,19 \cdot 63$ & $4 \cdot 09$ & $0.58,17 \cdot 54$ \\
\hline New Zealand European & $1 \cdot 00$ & & $1 \cdot 00$ & \\
\hline \multicolumn{5}{|c|}{ Any infant or follow-on formula } \\
\hline No & $4 \cdot 84$ & $2 \cdot 62,8 \cdot 03$ & $5 \cdot 69$ & $2 \cdot 66,10 \cdot 16$ \\
\hline Yes & 1.00 & & $1 \cdot 00$ & \\
\hline \multicolumn{5}{|c|}{ Child currently taking vitamin supplements } \\
\hline No & $3 \cdot 91$ & $2 \cdot 24,6 \cdot 57$ & $5 \cdot 32$ & $2 \cdot 04,11 \cdot 85$ \\
\hline Yes & $1 \cdot 00$ & & $1 \cdot 00$ & \\
\hline \multicolumn{5}{|l|}{ Person to room ratio } \\
\hline $1 \cdot 0$ or greater & $4 \cdot 11$ & $2 \cdot 30,6 \cdot 68$ & $2 \cdot 36$ & $1 \cdot 04,4 \cdot 86$ \\
\hline$<1 \cdot 0$ & $1 \cdot 00$ & & $1 \cdot 00$ & \\
\hline
\end{tabular}

$\mathrm{RR}$, relative risk.

${ }^{*}$ Relative risks and $95 \%$ confidence intervals weighted for ethnicity and adjusted for clustering.

tSample size for multivariate model $=348$.

20.11), not receiving any infant or follow-on formula $(\mathrm{RR}=5 \cdot 69,95 \%$ CI $2 \cdot 66,10 \cdot 16)$, not currently receiving vitamin supplements $(\mathrm{RR}=5 \cdot 32,95 \% \mathrm{CI} 2 \cdot 04,11 \cdot 85)$ and living in a more crowded household ( $\mathrm{RR}=2 \cdot 36,95 \% \mathrm{CI}$ $1 \cdot 04,4 \cdot 86)$.

\section{Discussion}

Vitamin D deficiency is prevalent in the first two years of life in New Zealand, particularly among Pacific children. There was more than a 5-fold variability in prevalence with season, with this magnitude of seasonal effect evident during both winter and spring. The limited dietary sources of additional vitamin D available in New Zealand through supplementation or using fortified milk formula were both independently protective against vitamin D deficiency.

The vitamin D-deficient children identified in the present sample were dissimilar in several respects from those described in recent series from developed countries. Unlike many other studies of young urban children, the vitamin D-deficient children in the current sample were not of low height- or weight-for-age ${ }^{(30-33)}$. Neither breast-feeding past 6 months of age nor restrictive diets were associated with an increased risk of vitamin D deficiency ${ }^{(34,35)}$. In the present study inadequate dietary intake of vitamin D was not due to any parental omission or deliberate dietary restriction. The children were placed at dietary risk because there is no current policy that seeks to ensure adequate vitamin D status except for infants born at less than 32 weeks' gestation or $1800 \mathrm{~g}$ birth weight ${ }^{(10)}$.

Although most measures of sunlight exposure were not associated with the risk of vitamin D deficiency, a very strong seasonal effect was evident. Auckland has mild but wet winters with on average more rainy days per month than London, Birmingham or Edinburgh for seven of the twelve calendar months, and an average of only $4 \cdot 3 \mathrm{~h}$ of sunshine per day during the winter months (June, July and August) ${ }^{(36)}$. Relative to similar northern hemisphere latitudes, most of New Zealand's excess UV irradiation occurs during the summer months. Auckland (36 $52^{\prime} \mathrm{S}$ ) lies at a similar latitude to European cities where vitamin $\mathrm{D}$ deficiency has recently been shown to be prevalent in breast-fed infants; for example, Athens ${ }^{(37)}\left(37^{\circ} 59^{\prime} \mathrm{N}\right)$ and Ioannina ${ }^{(38)}\left(39^{\circ} 42^{\prime} \mathrm{N}\right)$ in Greece and Pisa ${ }^{(39)}$ in Italy $\left(43^{\circ} 43^{\prime} \mathrm{N}\right)$. In these countries, like Auckland, there has been a misperception that because of high summer sunlight intensity vitamin D supplementation in early childhood is unnecessary.

Increased skin pigmentation is one of the factors that explain the increased frequency of vitamin D deficiency in non-European ethnic groups. Clearly though, it is not the sole nor necessarily the most significant factor ${ }^{(40)}$. Generally speaking, the skin pigmentation of Maori and Pacific peoples is similar; however, the risk of vitamin D deficiency for Pacific children was twice that for Maori ( $\mathrm{RR}=2 \cdot 18$, 95\% CI $1 \cdot 09,3 \cdot 83)$.

Ethnic-specific dietary habits alter the risk of rickets. In the UK, the higher frequency of rickets in Asian (Pakistani and Indian) children in comparison with children with more pigmented skin was thought to be due to the higher phytate content of their diet ${ }^{(41,42)}$. However, the mechanism of this effect is primarily by reducing the bioavailability of dietary Ca rather than any specific effect on vitamin $\mathrm{D}^{(43)}$. Ethnic differences in the frequency of the genetic polymorphisms which regulate vitamin $\mathrm{D}$ receptor activity explain differing risks of disease associated with vitamin D 
deficiency but not vitamin D concentrations themselves $^{(44)}$. Thus it seems more likely that cultural and lifestyle rather than genetic differences explain the increased risk of vitamin D deficiency in Pacific people.

There was an increased risk of vitamin D deficiency associated with two measures of lower socio-economic status: higher expenditure to income ratios and more crowded households. Living in poor urban households is recognised as a risk factor for rickets both in countries with and without high sunlight exposure ${ }^{(30,45)}$. It is likely to be the most significant factor contributing to the excessive risk of vitamin D deficiency in Pacific children. Within New Zealand, Pacific people have the highest level of food insecurity and more than $40 \%$ of New Zealand Pacific people live in crowded housing ${ }^{(46,47)}$.

The vitamin $\mathrm{D}$ deficiency evident in the present sample is likely to have several adverse effects on the health of these children. Vitamin D deficiency in early childhood may have long-term adverse effects on skeletal bone mineralisation in addition to causing rickets ${ }^{(48)}$. It may also play a causative role in periodontal disease ${ }^{(49)}$. Vitamin D deficiency (as manifested by rickets) is associated an increased risk of subsequent development of type 1 diabetes ${ }^{(50-52)}$.

Vitamin D influences the function of both the innate and adaptive immune systems. Vitamin D increases the production of innate antimicrobial peptides and promotes the induction of T-regulatory cells ${ }^{(53,54)}$. These immune modulator effects provide a potential explanation for the increased risk of pneumonia that is associated with rickets in children of pre-school age and with the increased risk of wheezy respiratory illnesses in children whose mothers had lower intakes of vitamin D during pregnancy ${ }^{(55)}$. The potential role that vitamin D deficiency plays in the excessive burden of lower respiratory tract disease experienced by New Zealand children requires further examination $^{(56)}$.

The poor vitamin D status of the young children in the present study is consistent with that described for New Zealand adults and school-aged children. A national nutrition survey of adults in 1997 showed that the mean vitamin D concentration $(50 \mathrm{nmol} / \mathrm{l})$ of New Zealand adults was lower than the mean value recorded in the adult US population $(>70 \mathrm{nmol} / \mathrm{l})$ living at comparable latitudes $^{(57,58)}$. A national survey of children aged 5 to 14 years in 2002 showed that the mean vitamin D concentration was also $50 \mathrm{nmol} / \mathrm{l}^{(59)}$. This population average is lower than that reported for the UK population aged 4 to 10 years (mean $\approx 70 \mathrm{nmol} / \mathrm{l}$ ) and 11 to 14 years (mean $56 \mathrm{nmol} / \mathrm{l})^{(59,60)}$. Suboptimal vitamin D status therefore appears to be a public health issue in New Zealand from infancy through adulthood.

Thus the public health strategy to address this issue for young children needs to consider the vitamin D status of the child and mother, and is likely to require both vitamin D supplementation and vitamin D fortification of staple foods. In vitamin D-sufficient women, breast milk vitamin D concentration ranges from 15 to $50 \mathrm{IU} / 1$ and is even lower in women who are vitamin D-deficient ${ }^{(61)}$. Therefore policy that recommends vitamin D supplementation for breast-fed infants and those not consuming sufficient infant formula to meet their daily requirements will be necessary if currently recommended intakes in infancy $(200 \mathrm{IU} / \mathrm{d})$ are to be $\mathrm{met}^{(7)}$. The poor compliance with daily vitamin supplementation of infants in the UK suggests that alternative strategies, such as less frequent dosing administered at well child visits, requires consideration $^{(62)}$. The protection against vitamin D deficiency provided by infant formula consumption in our study indicates that supplementation of other milks and solid foods consumed by young children is also likely to be beneficial.

Improving maternal vitamin D status is essential if infant vitamin D status is to be normal from birth. Newborn infant vitamin D status is determined by maternal vitamin D status during pregnancy ${ }^{(63)}$. Both mandatory fortification and vitamin D supplementation would appear to be necessary to achieve adequate maternal and therefore newborn vitamin D status. In the New Zealand adult nutrition survey more than $50 \%$ of women aged 19 to 44 years had vitamin D concentrations $\leq 50 \mathrm{nmol} / 1$ and more than $80 \%$ had concentrations $\leq 80 \mathrm{nmol} / \mathrm{l}^{(57)}$. The intake of vitamin D from dietary sources in New Zealand is not known ${ }^{(57)}$. Based on literature from other countries that do not have mandatory fortification, intake is likely to be well below the currently recommended intake of $200 \mathrm{IU} / \mathrm{d}^{(57)}$.

Mandatory fortification of food with vitamin D would be expected to increase vitamin D intake ${ }^{(64)}$. However, in countries where this is already policy, it is not sufficient to prevent vitamin D deficiency in higher-risk groups ${ }^{(64)}$. Maternal supplementation during pregnancy would also seem necessary. The dose required is likely to be higher than the currently recommended 200-400 IU/d and compliance issues indicate that alternatives to daily supplementation need to be considered ${ }^{(65-67)}$.

In conclusion, the present study shows that the prevalence of vitamin D deficiency is such that it is liable to be having an adverse effect on child health in New Zealand. It could well be one of the more important factors that determine the poorer health status of Maori and Pacific children in New Zealand. New Zealand must develop health policy which reflects the needs of its ethnically diverse population.

\section{Acknowledgements}

This project was funded by the Health Research Council of New Zealand Project Grant \# 99/075. The authors have no competing interests to declare. All authors were involved in the design of the study. C.C.G. and C.R.W. 
supervised the collection of the data. C.C.G. and C.R.W. performed the majority of the data analysis with guidance and interpretation from R.S. and S.C. C.C.G. completed the first draft of the manuscript which was edited and revised by C.R.W., S.C. and R.S.

\section{References}

1. Central Intelligence Agency (2007) The World Factbook New Zealand. http://www.cia.gov/library/publications/theworld-factbook/print/nz.html (accessed July 2007).

2. Cancer Society of New Zealand (2003) Position statement: Skin cancer prevention and early detection. http://www. sunsmart.org.nz/media/4166/csnz_ps_skin-1.pdf (accessed July 2007).

3. Health Sponsorship Council (2005) Position Statement: The Risks and Benefits of Sun Exposure in New Zealand. http:// www.sunsmart.org.nz/skin-cancer-control-in-nz/positionstatements/risks-and-benefits-of-sun-exposure.aspx (accessed May 2007).

4. McKenzie RL, Bodeker GE, Keep DJ, Kotkamp M \& Evans J (1996) UV radiation in New Zealand: north-to-south differences between two sites and relationship to other latitudes. Weather Climate 16, 17-26.

5. McKenzie RL, Johnston P \& Liley B (2006) Huge seasonal and latitudinal variability in vitamin-D production from sunlight. $N Z$ Fam Physician 33, 87-88.

6. Shaw NJ \& Pal BR (2002) Vitamin D deficiency in UK Asian families: activating a new concern. Arch Dis Child 86, 147-149.

7. Gartner LM \& Greer F (2003) Prevention of rickets and vitamin D deficiency: new guidelines for vitamin D intake. Section on Breastfeeding and Committee on Nutrition. Pediatrics 111, 908-910.

8. Department of Health and Ageing, Australian Government, Australian National Health and Medical Research Council \& New Zealand Ministry of Health (2006) Nutrient reference Values for Australia and New Zealand Including Recommended Dietary Intakes. Canberra: Commonwealth of Australia; available at http://www.nhmrc.gov.au/publications/ synopses/n35syn.htm

9. Ministry of Health (2006) Food and Nutrition Guidelines for Healthy Pregnant and Breastfeeding Women: A Background Paper. Wellington: Ministry of Health.

10. Cormack B \& Kushel C (2005) Neonatal Nutrition Guideline. Auckland: Auckland District Health Board.

11. Charlton K (2003) Auckland Regional Public Health Service Nutrition Fact Sheet - Vitamin D Deficiency. Auckland: Auckland Regional Public Health Service.

12. Blok BH, Grant CC, McNeil AR \& Reid IR (2000) Characteristics of children with florid vitamin D deficient rickets in the Auckland region in 1998. N Z Med J 113, 374-376.

13. Walker R (1993) The People in the North Health Region. Auckland: Northern Regional Health Authority.

14. Grant CC, Wall CR, Brunt D, Crengle S \& Scragg R (2007) Population prevalence and risk factors for iron deficiency in Auckland, New Zealand. J Paediatr Child Health 43, 532-538.

15. Statistics New Zealand (2003) 2001 Census of Population and Dwellings. Wellington: Statistics New Zealand.

16. Dean AG, Arner TG, Sunki GG et al. (2002) Epi Info ${ }^{T M}, A$ Database and Statistics Program for Public Health Professionals. Atlanta, GA: Centers for Disease Control and Prevention.

17. Crampton P \& Davis P (1998) Measuring deprivation and socioeconomic status: why and how? NZ Public Health Rep $\mathbf{5}$, issue $11 / 12,81-84$.
18. Salmond C \& Crampton P (2002) NZDep2001 Index of Deprivation. Wellington: University of Otago.

19. Siegel LJ \& Peterson L (1980) Stress reduction in young dental patients through coping skills and sensory information. J Consult Clin Psychol 48, 785-787.

20. Lawson M \& Thomas M (1999) Vitamin D concentrations in Asian children aged 2 years living in England: population survey. BMJ 318, 28.

21. Institute of Medicine, Food and Nutrition Board, Standing Committee on the Scientific Evaluation of Dietary Reference Intakes (1997) Vitamin D. In Dietary Reference Intakes for Calcium, Phosphorus, Magnesium, Vitamin D, and Fluoride, pp. 250-287. Washington, DC: National Academy Press.

22. Ceriotti F \& Ceriotti G (1980) Improved direct specific determination of serum iron and total iron-binding capacity. Clin Chem 26, 327-331.

23. Anon. (1985) Summary of a report on assessment of the iron nutritional status of the United States population. Expert Scientific Working Group. Am J Clin Nutr $\mathbf{4 2}$, 1318-1330.

24. Looker AC, Dallman PR, Carroll MD, Gunter EW \& Johnson CL (1997) Prevalence of iron deficiency in the United States. JAMA 277, 973-976.

25. Scragg R, Jackson R, Holdaway IM, Lim T \& Beaglehole R (1990) Myocardial infarction is inversely associated with plasma 25-hydroxyvitamin $\mathrm{D}_{3}$ levels: a community-based study. Int J Epidemiol 19, 559-563.

26. Zhang J \& Yu KF (1998) What's the relative risk? A method of correcting the odds ratio in cohort studies of common outcomes. JAMA 280, 1690-1691.

27. Food Standards Australia and New Zealand (2008) Australia New Zealand Food Standards Code. Canberra: Commonwealth of Australia.

28. Statistics New Zealand (2007) Crowding Measures by Ethnic Group. Housing Quality Statistics. Wellington: Statistics New Zealand.

29. Statistics New Zealand (2002) Employment and Income of Pacific Peoples in New Zealand. Wellington: Statistics New Zealand.

30. Arneil GC \& Crosbie JC (1963) Infantile rickets returns to Glasgow. Lancet 2, 423-425.

31. Benson PF, Stroud CE, Mitchell NJ \& Nicolaides A (1963) Rickets in immigrant children in London. $\mathrm{Br}$ Med $J \mathbf{1}$, 1054-1056.

32. Bachrach S, Fisher J \& Parks JS (1979) An outbreak of vitamin D deficiency rickets in a susceptible population. Pediatrics 64, 871-877.

33. Kreiter SR, Schwartz RP, Kirkman HN Jr, Charlton PA, Calikoglu AS \& Davenport ML (2000) Nutritional rickets in African American breast-fed infants. J Pediatr 137, 153-157.

34. Gessner BD, Plotnik J \& Muth PT (2003) 25-Hydroxyvitamin D levels among healthy children in Alaska. J Pediatr 143, 434-437.

35. Edidin DV, Levitsky LL, Schey W, Dumbovic N \& Campos A (1980) Resurgence of nutritional rickets associated with breast-feeding and special dietary practices. Pediatrics $\mathbf{6 5}$, 232-235.

36. Anon. (2007) New Zealand's Climate. Information for New Zealand Cities 2007. http://www.emigratenz.org/new-zealand-climate.html (accessed July 2007).

37. Nicolaidou P, Hatzistamatiou Z, Papadopoulou A, Kaleyias J, Floropoulou E, Lagona E, Tsagris V, Costalos C \& Antsaklis A (2006) Low vitamin D status in mother-newborn pairs in Greece. Calcif Tissue Int 78, 337-342.

38. Challa A, Ntourntoufi A, Cholevas V, Bitsori M, Galanakis E \& Andronikou S (2005) Breastfeeding and vitamin D status in Greece during the first 6 months of life. Eur J Pediatr 164, 724-729. 
39. Baroncelli GI, Bertelloni S, Ceccarelli C, Amato V \& Saggese G (2000) Bone turnover in children with vitamin $\mathrm{D}$ deficiency rickets before and during treatment. Acta Paediatr 89, 513-518.

40. Clemens TL, Adams JS, Henderson SL \& Holick MF (1982) Increased skin pigment reduces the capacity of skin to synthesise vitamin $\mathrm{D}_{3}$. Lancet $\mathbf{1}, 74-76$.

41. Wills MR, Phillips JB, Day RC \& Bateman EC (1972) Phytic acid and nutritional rickets in immigrants. Lancet $\mathbf{1}$, 771-773.

42. Preece MA, McIntosh WB, Tomlinson S, Ford JA, Dunnigan MG \& O'Riordan JL (1973) Vitamin-D deficiency among Asian immigrants to Britain. Lancet 1, 907-910.

43. Ma G, Li Y, Jin Y, Zhai F, Kok FJ \& Yang X (2007) Phytate intake and molar ratios of phytate to zinc, iron and calcium in the diets of people in China. Eur J Clin Nutr 61, 368-374.

44. Jurutka PW, Whitfield GK, Hsieh JC, Thompson PD, Haussler CA \& Haussler MR (2001) Molecular nature of the vitamin D receptor and its role in regulation of gene expression. Rev Endocr Metab Disord 2, 203-216.

45. Salimpour R (1975) Rickets in Tehran. Study of 200 cases. Arch Dis Child 50, 63-66.

46. Parnell WR, Reid J, Wilson NC, McKenzie J \& Russell DG (2001) Food security: is New Zealand a land of plenty? $N Z$ Med J 114, 141-145.

47. Anon. (2007) The Social Report 2006. Wellington: Ministry of Social Development.

48. Cooper C, Javaid K, Westlake S, Harvey N \& Dennison E (2005) Developmental origins of osteoporotic fracture: the role of maternal vitamin D insufficiency. J Nutr 135, Suppl., 2728S-2734S.

49. Dietrich T, Joshipura KJ, Dawson-Hughes B \& BischoffFerrari HA (2004) Association between serum concentrations of 25-hydroxyvitamin $\mathrm{D}_{3}$ and periodontal disease in the US population. Am J Clin Nutr 80, 108-113.

50. Zipitis CS \& Akobeng AK (2008) Vitamin D supplementation in early childhood and risk of type 1 diabetes: a systematic review and meta-analysis. Arch Dis Child 93, 512-517.

51. Mathieu C, Gysemans C, Giulietti A \& Bouillon R (2005) Vitamin D and diabetes. Diabetologia 48, 1247-1257.

52. Hypponen E, Laara E, Reunanen A, Jarvelin MR \& Virtanen SM (2001) Intake of vitamin D and risk of type 1 diabetes: a birth-cohort study. Lancet 358, 1500-1503.

53. Zasloff M (2006) Fighting infections with vitamin D. Nat Med 12, 388-390.

54. Meehan MA, Kerman RH \& Lemire JM (1992) 1,25Dihydroxyvitamin $\mathrm{D}_{3}$ enhances the generation of nonspecific suppressor cells while inhibiting the induction of cytotoxic cells in a human MLR. Cell Immunol 140, 400-409.

55. Camargo CA Jr, Rifas-Shiman SL, Litonjua AA, Rich-Edwards JW, Weiss ST, Gold DR, Kleinman K \& Gillman MW (2007) Maternal intake of vitamin D during pregnancy and risk of recurrent wheeze in children at 3 y of age. Am J Clin Nutr 85, 788-795.

56. Grant CC \& Milne R (2006) What does pneumonia cost New Zealand? In Burden of Preventable Breathing Diseases in Children and Young People, pp. 35-39 [MI Asher and C Byrnes, editors]. Wellington: Asthma and Respiratory Foundation of New Zealand.

57. Rockell JE, Skeaff CM, Williams SM \& Green TJ (2006) Serum 25-hydroxyvitamin D concentrations of New Zealanders aged 15 years and older. Osteoporos Int 17, 1382-1389.

58. Looker AC, Dawson-Hughes B, Calvo MS, Gunter EW \& Sahyoun NR (2002) Serum 25-hydroxyvitamin D status of adolescents and adults in two seasonal subpopulations from NHANES III. Bone 30, 771-777.

59. Rockell JE, Green TJ, Skeaff CM et al. (2005) Season and ethnicity are determinants of serum 25-hydroxyvitamin D concentrations in New Zealand children aged 5-14 y. J Nutr 135, 2602-2608.

60. Gregory JR, Lowe S, Bates CJ, Prentice A, Jackson LV, Smithers G, Wenlock R \& Farron M (2001) National Diet and Nutrition Survey: Young People Aged 4 to 18 Years. vol. 1: Report of the Diet and Nutrition Survey. London: TSO.

61. Leerbeck E \& Sondergaard H (1980) The total content of vitamin $\mathrm{D}$ in human milk and cow's milk. Br J Nutr $\mathbf{4 4}$, $7-12$.

62. Leaf AA (2007) Vitamins for babies and young children. Arch Dis Child 92, 160-164.

63. Fraser DR (1995) Vitamin D. Lancet 345, 104-107.

64. Calvo MS, Whiting SJ \& Barton CN (2005) Vitamin D intake: a global perspective of current status. J Nutr 135, 310-316.

65. Vieth R, Bischoff-Ferrari H, Boucher BJ et al. (2007) The urgent need to recommend an intake of vitamin $\mathrm{D}$ that is effective. Am J Clin Nutr 85, 649-650.

66. Williams AF (2007) Vitamin D in pregnancy: an old problem still to be solved? Arch Dis Child $\mathbf{9 2}, 740-741$.

67. Saadi HF, Dawodu A, Afandi BO, Zayed R, Benedict S \& Nagelkerke N (2007) Efficacy of daily and monthly highdose calciferol in vitamin D-deficient nulliparous and lactating women. Am J Clin Nutr 85, 1565-1571. 